[Regular Paper]

\title{
Experimental Investigation into Effects of Crude Oil Acid and Base Number on Wettability Alteration by Using Different Low Salinity Water in Sandstone Rock
}

\author{
Abdolmohsen SHABIB-AsL*, Mohammed Abdalla Ayoub, Ismail Mohd SAAID, and Pedro Paulo Jose VALENTIM \\ Dept. of Petroleum Engineering, Faculty of Geoscience and Petroleum Engineering, Universiti Teknologi PETRONAS (UTP), \\ Bandar Seri Iskandar, 32610, Tronoh, Perak, MALAYSIA
}

(Received September 30, 2014)

\begin{abstract}
In the last two decades, the level of investigation into low salinity water (LSW) flooding has sharply increased. LSW with adequate composition and salinity is injected into the reservoir, which changes the properties of the reservoir rock, thus improving oil recovery. However, for certain reservoirs there might be no improvement at all. This has led for further studies on what exactly governs the lack of improvement upon LSW injection in different reservoirs. Focus was placed on acidic and basic components present in crude oil. They are characterized by measuring total acid number (TAN) and total base number (TBN). This study investigates the wettability alteration of Berea sandstone rock with different crude oil acid and base numbers at specific LSW concentrations and compositions. For this purpose, the sessile drop method was used in specified times. Moreover, the experiments were conducted in two stages, which included crude oil A and B. The experimental results revealed that a significant change in wettability was experienced by the LSW composition of cations $\mathrm{K}^{+}$and $\mathrm{Na}^{+}$for the crude oil composition with lower acid number.
\end{abstract}

\section{Keywords}

Total acid number, Total base number, Low salinity water, Berea sandstone, Sessile drop method

\section{Introduction}

The LSW injection method has since gained wide attention and interest from many researchers. Nasralla et al. (2011), by conducting injection studies with deionized water and seawater, demonstrated that the former improved oil recovery significantly rather than the latter ${ }^{1)}$. With the purpose of enhancing oil recovery, low salinity water (LSW) with adequate composition and salinity is injected into the reservoir, which changes the wetting properties of the reservoir rock into that favoring oil recovery ${ }^{2), 3)}$. There are many theories regarding the mechanisms of wettability alteration in presence of LSW which are fine migration ${ }^{4}$, the $\mathrm{pH}$ effects $^{3)}$, multiple-component ion exchange (MIE) $)^{5)}$, and wettability modification due to double layer expansion $^{2), 6)}$. Ligthelm et al. (2009) suggested that the application of LSW results in an expansion of the ionic electrical double layer between the clay and the oil interfaces. This causes the oil to be desorbed from the rock surface thus increasing the water wetness ${ }^{6}$.

Residual oil determination is in part dependent on the wettability of the rock. Wettability measurements are

DOI: dx.doi.org/10.1627/jpi.58.228

* To whom correspondence should be addressed.

* E-mail: msn.shabib@gmail.com performed in laboratory by several methods. Among many, there are the sessile drop method and zeta potential, which provide the results in terms of contact angle. For this case, the degree of wetness is determined following certain classifications. According to Fanchi et al. (2010), a reservoir rock is considered strongly water wet if the contact angle with reference to water varies between $0-30^{\circ}$; moderately water wet is from $30-70^{\circ}$; neutrally wet $75-105^{\circ}$; moderately oil-wet $105-150^{\circ}$ and finally $150-180^{\circ}$ for strongly oil-wet ${ }^{7)}$.

\section{LSW Mechanism}

Clay minerals constitute the major percentage of sedimentary rocks and they have negative surface charge ${ }^{8)}$. This property causes the positively charged ions to adhere to it as in the case of $\mathrm{Ca}^{2+}, \mathrm{Mg}^{2+}, \mathrm{Na}^{+}$, or $\mathrm{K}^{+}$. Ions such as $\mathrm{Ca}^{2+}$ and $\mathrm{Mg}^{2+}$ are called divalent cations. They are present in great amounts in the formation water and assist in adsorption of oil onto the surfaces of the rock. This eventually creates oil-wet conditions for the rock and thus causing most of it to be trapped within the reservoir ${ }^{5)}$. Upon LSW injection (Fig. 1(a)) and due to the ion exchange capability of the clay minerals, there is replacement of the divalent cations by the monovalent cations. The divalent cations leave the rock surfaces along with the desorbed oil (Fig. 1(b)). 


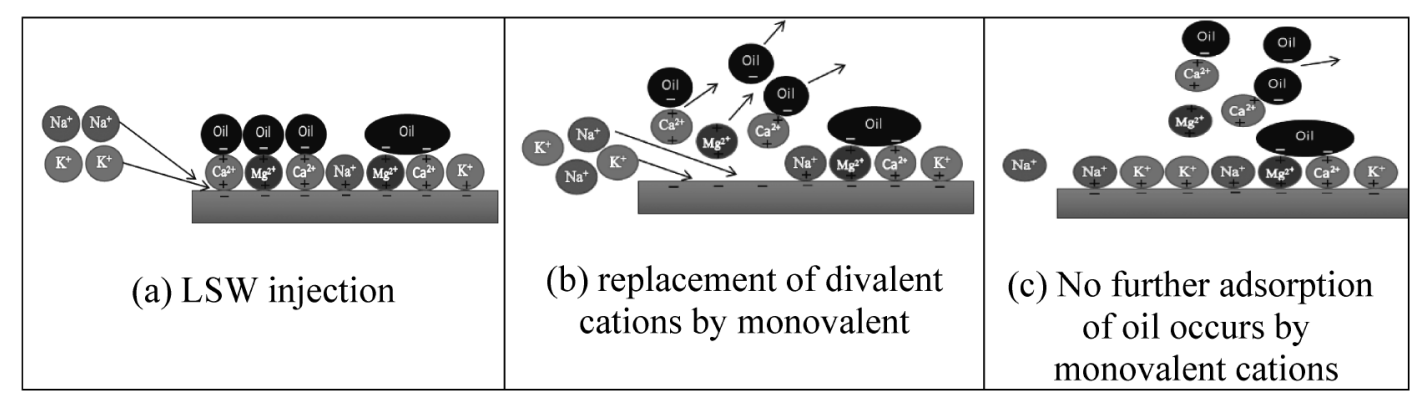

Fig. 1 MIE Mechanism Process

Table 1 Properties of the Rock from the Company

\begin{tabular}{ccccc}
\hline Formation & $K[\mathrm{mD}]$ & $\varphi[\%]$ & UCS & Dimension \\
\hline Kipton & $100 \mathrm{mD}$ brine permeability & $20 \%$ & $6500-8000 \mathrm{psi}$ & 1.5 inch $(\mathrm{D}) \times 12$ inch $(\mathrm{L})$ \\
\hline
\end{tabular}

Table 2 Rock Sample Properties Measured by the Poroperm Machine

\begin{tabular}{cccccccc}
\hline$K_{\text {[gas }]}[\mathrm{mD}]$ & $b[\mathrm{psi}]$ & $\beta\left[\mathrm{ft}^{-4}\right]$ & $V_{\mathrm{p}}\left[\mathrm{cm}^{3}\right]$ & $V_{\mathrm{g}}\left[\mathrm{cm}^{3}\right]$ & $\varphi[\%]$ & $V_{\mathrm{b}}\left[\mathrm{cm}^{3}\right]$ & $\mathrm{Grain} \mathrm{density}$ \\
\hline 161.378 & $9.18 \mathrm{E}-06$ & $-1.28 \mathrm{E}+07$ & 16.137 & 67.911 & 19.199 & 84.048 & 2.632 \\
\hline
\end{tabular}

Since the monovalent ions are one ended, their adsorption to clay surfaces causes no further oil to be adsorbed and thus creating a water wet condition (Fig. 1(c)). The aforementioned methods constitute what is called the multiple-component ion exchange (MIE) mechanism ${ }^{5}$.

\section{Materials}

\section{1. Rock}

The reservoir rock was obtained from the KOCUREK Co. (USA). Its additional properties as received from the company are displayed in the Table 1. Some of these properties were confirmed by performing mineral analysis by the X-ray diffractometer (XRD) and basic routine core analysis by the poroperm machine. Table 2 shows results obtained from the poreperm machine. The XRD analysis was conducted with the main aim of identifying the silica oxide based minerals and its pattern is displayed in the Fig. 2. Moreover, the Table 3 further summarizes results for mineral composition from XRD.

The values of permeability from Tables $\mathbf{1}$ and $\mathbf{2}$ are different. This is because of the different methods used for measuring it. The company permeability (Table 1) is brine measured while that of the poreperm is gas measured (Table 2). For gas-based permeability, the Klinkenberg effect is present which contributes to the high value of the permeability.

\section{2. Crude Oil}

The effectiveness of LSW is in part influenced by the

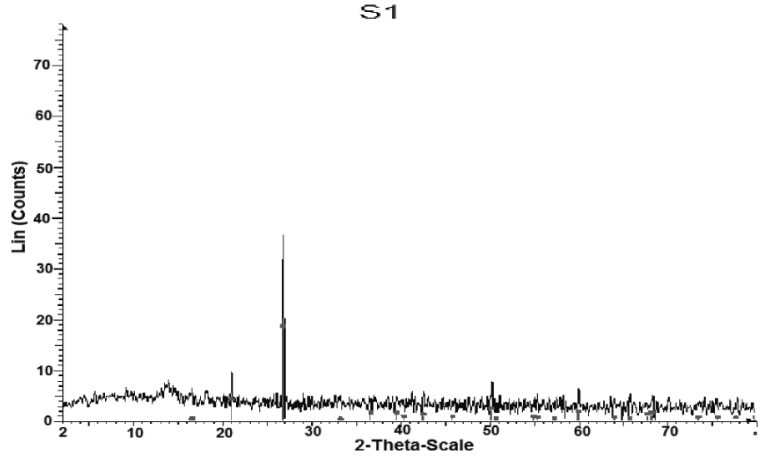

Fig. 2 Auto Indexing Pattern for Silicon Oxide-SiO

presence of polar components within the crude oil. No effect has been observed by the use of oil free from polar components ${ }^{2)}$. Total acid number (TAN) and total base number (TBN) are important parameters for characterizing the polar components within the crude oil. TAN is defined as the total amount of potassium hydroxide $(\mathrm{KOH})$ in milligrams, required for neutralizing $1 \mathrm{~g}$ of the petroleum acid in the crude oil; whereas, TBN is defined as the total amount of $\mathrm{KOH}$ in milligrams per $1 \mathrm{~g}$ of the crude oil $^{9)}$. Two samples of crude oil designated as crude oil A and B were used. Their specific total acid and base numbers were measured with reference to the TAN ASTM D 664 and TBN ASTM D 2896 standard methods by the use of METTLER TOLEDO Potentiometric Titrator. The results are summarized in the Tables $\mathbf{4}$ and $\mathbf{5}$. From the tables, it is patent that crude oil A has higher TAN and 
Table 3 Mineral Composition from the XRD

\begin{tabular}{cccccccccc}
\hline $\begin{array}{c}\mathrm{SiO}_{2} \\
\text { (silica) }\end{array}$ & $\begin{array}{c}\mathrm{Al}_{2} \mathrm{O}_{3} \\
\text { (alumina) }\end{array}$ & $\begin{array}{c}\mathrm{FeO}^{2} \mathrm{Fe}_{2} \mathrm{O}_{3} \\
\text { (iron oxide) }\end{array}$ & $\begin{array}{c}\mathrm{TiO}_{2} \\
\text { (titanium oxide) }\end{array}$ & $\begin{array}{c}\mathrm{CaO} \\
\text { (calcium oxide) }\end{array}$ & $\begin{array}{c}\mathrm{MgO} \\
\text { (magnesium oxide) }\end{array}$ & Alkalies & $\begin{array}{c}\mathrm{H}_{2} \mathrm{O} \\
\text { (water) }\end{array}$ & Undetermined \\
\hline 86.47 & 7.31 & 1.14 & 0.70 & 1.21 & 0.11 & 1.65 & 1.20 & 0.21 \\
\hline
\end{tabular}

Table 4 Total Acid and Base Number of the Crude Oil A

\begin{tabular}{ccccc}
\hline TAN $[\mathrm{mgKOH} / \mathrm{g}]$ & $\mathrm{TBN}[\mathrm{mgKOH} / \mathrm{g}]$ & Density $\left[\mathrm{g} / \mathrm{cm}^{3}\right\}$ & Viscosity $\left[\mathrm{cP}\right.$ at $\left.25^{\circ} \mathrm{C}\right]$ & Viscosity $\left[\mathrm{cP}\right.$ at $\left.85{ }^{\circ} \mathrm{C}\right]$ \\
\hline 0.667 & 0.146 & 0.821 & 3.761 & 1.464 \\
\hline $1 \mathrm{cP}=1 \times 10^{-3} \mathrm{~Pa} \mathrm{s.}$ & & &
\end{tabular}

Table 5 Total Acid and Base Number of the Crude Oil B

\begin{tabular}{ccccc}
\hline TAN $[\mathrm{mgKOH} / \mathrm{g}]$ & $\mathrm{TBN}[\mathrm{mgKOH} / \mathrm{g}]$ & Density $\left[\mathrm{g} / \mathrm{cm}^{3}\right]$ & Viscosity $\left[\mathrm{cP}\right.$ at $\left.25^{\circ} \mathrm{C}\right]$ & Viscosity $\left[\mathrm{cP}\right.$ at $\left.85^{\circ} \mathrm{C}\right]$ \\
\hline 0.174 & 0.750 & 0.813 & 3.085 & 1.233 \\
\hline
\end{tabular}

$1 \mathrm{cP}=1 \times 10^{-3} \mathrm{~Pa} \mathrm{~s}$.

lower TBN as compared to crude oil B that has lower TAN and higher TBN.

\section{3. Brine Properties}

The brines for LSW were prepared by mixing controlled amounts of $\mathrm{K}^{+}, \mathrm{Na}^{+}, \mathrm{Ca}^{2+}, \mathrm{Mg}^{2+}$, and $\mathrm{Cl}^{-}$salts with distilled water. Initial connate water saturation for the rock was obtained by the use of formation water prepared with high concentration of $\mathrm{Ca}^{2+}$ and $\mathrm{Mg}^{2+}$ cations with other amounts of $\mathrm{HCO}_{3}{ }^{-}, \mathrm{SO}_{4}{ }^{2-}, \mathrm{K}^{+}, \mathrm{Na}^{+}$, and $\mathrm{Cl}^{-}$. Table 6 summarizes the properties of all brines.

\section{Methodology}

Figure 3 shows a schematic drawing of the experimental procedures. The first step consisted in extracting 62 core slices from the core plugs. Then the slices were polished and cleaned with toluene. Next, they were dried in oven at $105{ }^{\circ} \mathrm{C}$ for about $24 \mathrm{~h}$. The second step entailed the saturation of the core slices with formation water (FW) by using a vacuum pump for 2 to $4 \mathrm{~h}$. After saturation, the slices were put in the oven for nearly $72 \mathrm{~h}$ at $80{ }^{\circ} \mathrm{C}$. Next, they were aged in crude oil (31 slices for crude oil A and 31 for crude oil B) at stabilized temperature of $80{ }^{\circ} \mathrm{C}$ for $72 \mathrm{~h}$. Finally, the slices were immersed in respective LSW enumerated from one to $30 \mathrm{LSW}_{1}-\mathrm{LSW}_{30}$ and formation water (Fig. 4)

Wettability measurement was performed by the sessile drop method using the IFT 700 equipment (Fig. 5). Here, results were recorded after each 0, 6, 12 and $24 \mathrm{~h}$ by taking photos of the water drop shape on the slices (Figs. 6-11). This procedure was repeated for all the compositions. In addition, the experiments were performed in two stages each of which focused on each type of oil (crude oil A and B). The methods described above, follow a modification from the standard ones by Shabib-Asl et al. $(2014)^{10)}$.

\section{Results}

Figures 12 through 16 represent changes of contact angle with time for the $\mathrm{NaCl}, \mathrm{KCl}, \mathrm{MgCl}_{2}, \mathrm{CaCl}_{2}, \mathrm{FW}$ compositions and the mixture of all of these components for the crude oil A and B. The concentrations of LSW are varying from 500 to $6500 \mathrm{ppm}$. Here, for all LSW compositions and concentrations, the contact angle is changing throughout the time except for the formation water composition that depicts no appreciable changes.

\section{1. KCl Composition}

Figure 12 depicts changes of contact angle for the $\mathrm{KCl}$ composition. Both crude oil $\mathrm{A}$ and $\mathrm{B}$ create different effects for the set intervals of time. Furthermore, the changes of contact angle for crude oil $\mathrm{B}$ are larger and faster than crude oil A. For instance, at the end of $24 \mathrm{~h}$, the change of contact angle for LSW20 for crude oil B is greater than that of LSW-20 for crude oil A (approximately 110 to $55^{\circ}$ versus 110 to $65^{\circ}$, respectively) as shown in Fig. 12.

In Fig. 12A), the contact angle decreases steadily and rapidly from zero to $12 \mathrm{~h}$. However, from 12 to $24 \mathrm{~h}$, the decrease in contact angle is slow. For the interval of $24 \mathrm{~h}$, the composition LSW-19 creates maximum change of contact angle (112 to $\left.62^{\circ}\right)$. Conversely, LSW-24 creates least changes of contact angle $\left(111\right.$ to $\left.89^{\circ}\right)$. For the Fig. 12B), the contact angle decreases rapidly from zero to $6 \mathrm{~h}$. From 6 to $12 \mathrm{~h}$ the decrease in contact angle is slow. From 12 to $24 \mathrm{~h}$, the contact angle continues to decrease slowly. For the whole interval of $24 \mathrm{~h}$, still the composition LSW19 causes largest changes of contact angle (112 to $\left.53^{\circ}\right)$. In contrast, LSW-24 causes smallest changes of contact angle $\left(111\right.$ to $\left.82^{\circ}\right)$. 
Table 6 Composition and Concentration of Different LSW

\begin{tabular}{|c|c|c|c|c|c|c|c|c|c|c|c|}
\hline & $\begin{array}{c}\mathrm{Na}^{+} \\
{[\mathrm{mg} / \mathrm{L}]}\end{array}$ & $\begin{array}{c}\mathrm{Ca}^{2+} \\
{[\mathrm{mg} / \mathrm{L}]}\end{array}$ & $\begin{array}{c}\mathrm{Mg}^{2+} \\
{[\mathrm{mg} / \mathrm{L}]}\end{array}$ & $\begin{array}{c}\mathrm{K}^{+} \\
{[\mathrm{mg} / \mathrm{L}]}\end{array}$ & $\begin{array}{l}\mathrm{HCO}_{3}^{-} \\
{[\mathrm{mg} / \mathrm{L}]}\end{array}$ & $\begin{array}{c}\mathrm{SO}_{4}{ }^{2-} \\
{[\mathrm{mg} / \mathrm{L}]}\end{array}$ & $\begin{array}{c}\mathrm{Cl}^{-} \\
{[\mathrm{mg} / \mathrm{L}]}\end{array}$ & $\begin{array}{c}\text { TDS } \\
{[\mathrm{mg} / \mathrm{L}]}\end{array}$ & $\begin{array}{l}\mathrm{pH} \text { at } \\
24^{\circ} \mathrm{C}\end{array}$ & $\begin{array}{l}\mathrm{pH} \text { at } \\
80{ }^{\circ} \mathrm{C}\end{array}$ & $\begin{array}{c}\text { Ionic } \\
\text { strength } \\
{[\mathrm{mole} / \mathrm{L}]}\end{array}$ \\
\hline LSW-1 (NaCl) & 196.7 & 0 & 0 & 0 & 0 & 0 & 303.3 & 500 & 6.81 & 6.71 & 0.008548 \\
\hline LSW-2 (NaCl) & 393.4 & 0 & 0 & 0 & 0 & 0 & 606.6 & 1000 & 6.75 & 6.68 & 0.017096 \\
\hline LSW-3 $(\mathrm{NaCl})$ & 983.5 & 0 & 0 & 0 & 0 & 0 & 1516.5 & 2500 & 6.69 & 6.67 & 0.042740 \\
\hline LSW-4 (NaCl) & 1376.8 & 0 & 0 & 0 & 0 & 0 & 2123.2 & 3500 & 6.63 & 6.60 & 0.059835 \\
\hline LSW-5 (NaCl) & 1770.3 & 0 & 0 & 0 & 0 & 0 & 2729.7 & 4500 & 6.62 & 6.58 & 0.076931 \\
\hline LSW-6 (NaCl) & 2557.1 & 0 & 0 & 0 & 0 & 0 & 3942.9 & 6500 & 6.59 & 6.50 & 0.111201 \\
\hline LSW-7 $\left(\mathrm{CaCl}_{2}\right)$ & 0 & 180.6 & 0 & 0 & 0 & 0 & 319.4 & 500 & 7.23 & 7.16 & 0.013517 \\
\hline LSW-8 $\left(\mathrm{CaCl}_{2}\right)$ & 0 & 361.2 & 0 & 0 & 0 & 0 & 638.8 & 1000 & 7.09 & 7.03 & 0.027034 \\
\hline LSW-9 $\left(\mathrm{CaCl}_{2}\right)$ & 0 & 903 & 0 & 0 & 0 & 0 & 1597 & 2500 & 6.91 & 6.81 & 0.067584 \\
\hline LSW-10 $\left(\mathrm{CaCl}_{2}\right)$ & 0 & 1264 & 0 & 0 & 0 & 0 & 2236 & 3500 & 6.85 & 6.80 & 0.094611 \\
\hline LSW-11 $\left(\mathrm{CaCl}_{2}\right)$ & 0 & 1625 & 0 & 0 & 0 & 0 & 2875 & 4500 & 6.82 & 6.78 & 0.121638 \\
\hline LSW-12 $\left(\mathrm{CaCl}_{2}\right)$ & 0 & 2347 & 0 & 0 & 0 & 0 & 4153 & 6500 & 6.80 & 6.76 & 0.175691 \\
\hline LSW-13 $\left(\mathrm{MgCl}_{2}\right)$ & 0 & 0 & 127.6 & 0 & 0 & 0 & 372.4 & 500 & 7.08 & 7.01 & 0.015755 \\
\hline LSW-14 $\left(\mathrm{MgCl}_{2}\right)$ & 0 & 0 & 255.3 & 0 & 0 & 0 & 744.7 & 1000 & 6.99 & 6.96 & 0.031516 \\
\hline LSW-15 $\left(\mathrm{MgCl}_{2}\right)$ & 0 & 0 & 638 & 0 & 0 & 0 & 1862 & 2500 & 6.91 & 6.87 & 0.078773 \\
\hline LSW-16 $\left(\mathrm{MgCl}_{2}\right)$ & 0 & 0 & 893 & 0 & 0 & 0 & 2607 & 3500 & 6.89 & 6.85 & 0.110268 \\
\hline LSW-17 $\left(\mathrm{MgCl}_{2}\right)$ & 0 & 0 & 1149 & 0 & 0 & 0 & 3351 & 4500 & 6.85 & 6.82 & 0.141831 \\
\hline LSW-18 $\left(\mathrm{MgCl}_{2}\right)$ & 0 & 0 & 1659 & 0 & 0 & 0 & 4841 & 6500 & 6.81 & 6.79 & 0.204822 \\
\hline LSW-19 (KCl) & 0 & 0 & 0 & 262.2 & 0 & 0 & 237.8 & 500 & 6.91 & 6.84 & 0.006710 \\
\hline LSW-20 (KCl) & 0 & 0 & 0 & 524.4 & 0 & 0 & 475.6 & 1000 & 6.89 & 6.83 & 0.013422 \\
\hline LSW-21 (KCl) & 0 & 0 & 0 & 1311 & 0 & 0 & 1189 & 2500 & 6.85 & 6.79 & 0.033554 \\
\hline LSW-22 (KCl) & 0 & 0 & 0 & 1835.4 & 0 & 0 & 1664.6 & 3500 & 6.81 & 6.76 & 0.046976 \\
\hline LSW-23 (KCl) & 0 & 0 & 0 & 2359.8 & 0 & 0 & 2140.2 & 4500 & 6.79 & 6.72 & 0.060397 \\
\hline LSW-24 (KCl) & 0 & 0 & 0 & 3408.6 & 0 & 0 & 3091.4 & 6500 & 6.78 & 6.71 & 0.087241 \\
\hline LSW-25 (Mix) & 19.7 & 18.1 & 12.8 & 183.5 & 0 & 0 & 265.9 & 500 & 6.83 & 6.77 & 0.008483 \\
\hline LSW-26 (Mix) & 39.4 & 36.2 & 178.6 & 52.4 & 0 & 0 & 693.4 & 1000 & 6.87 & 6.79 & 0.027816 \\
\hline LSW-27 (Mix) & 98.6 & 632 & 63.8 & 131.1 & 0 & 0 & 1574.5 & 2500 & 6.98 & 6.96 & 0.062825 \\
\hline LSW-28 (Mix) & 965.3 & 126.4 & 89.3 & 183.5 & 0 & 0 & 2135.5 & 3500 & 6.91 & 6.88 & 0.067201 \\
\hline LSW-29 (Mix) & 88.8 & 731.3 & 516.8 & 118 & 0 & 0 & 3045.1 & 4500 & 6.74 & 6.71 & 0.125424 \\
\hline LSW-30 (Mix) & 511.5 & 821.6 & 580.6 & 341 & 0 & 0 & 4245.3 & 6500 & 6.83 & 6.80 & 0.164191 \\
\hline $\mathrm{FW}$ most $\left(\mathrm{Ca}^{2+} \& \mathrm{Mg}^{2+}\right)$ & 5923.4 & 18310.1 & 12941.3 & 6818.2 & 472.2 & 1318.6 & 84216.2 & 130000 & 7.12 & 7.03 & 3.412470 \\
\hline
\end{tabular}

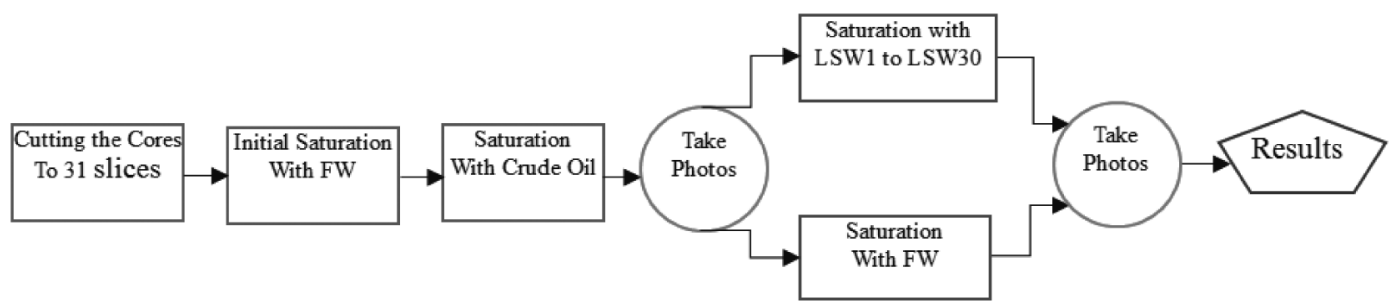

Fig. 3 Schematic Drawing of the Experimental Procedures
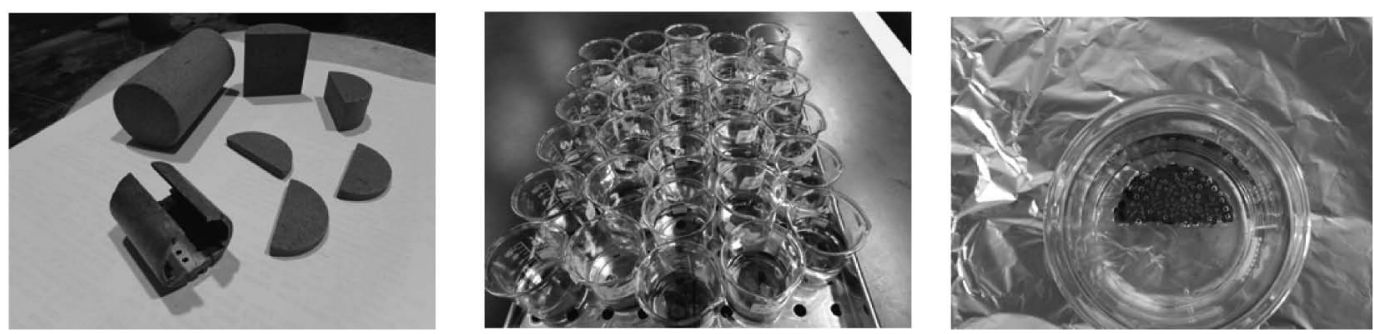

Fig. 4 Core Slices before and after Saturation with Brine 

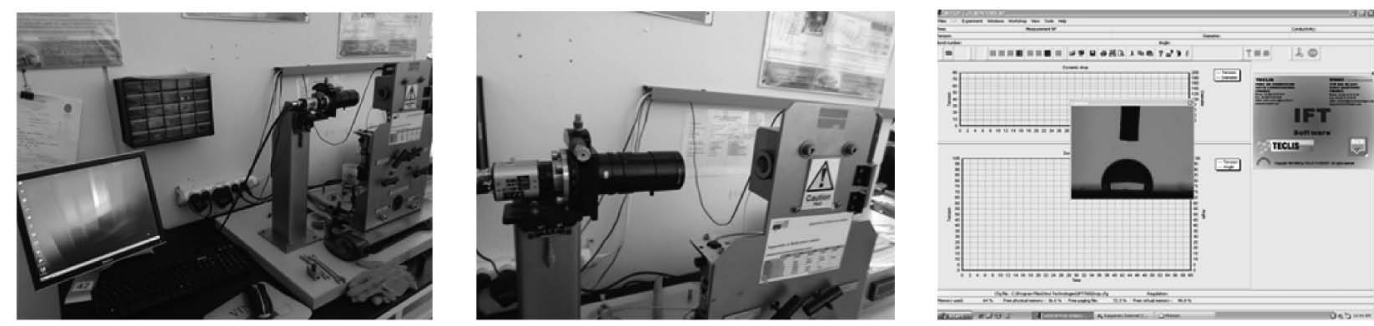

Fig. 5 IFT 700 Equipment for Contact Angle Measurements
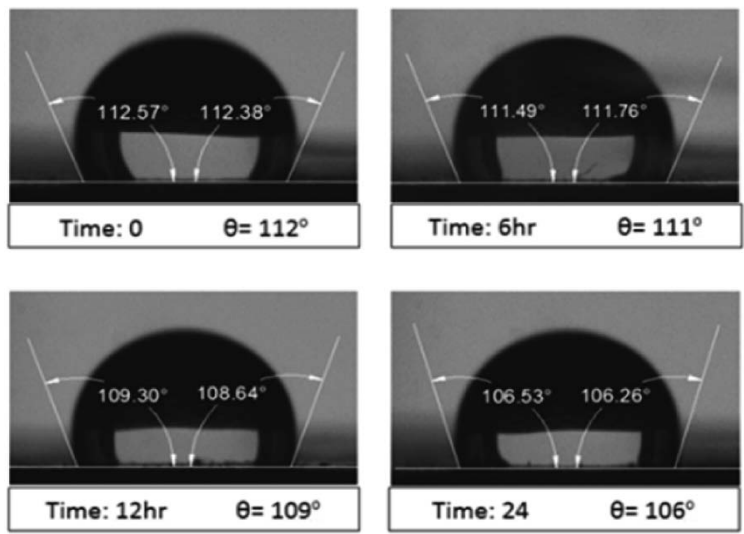

Fig. 6 Contact Angle Changes in Presence of Formation Water (FW-130,000 ppm)—Crude Oil A
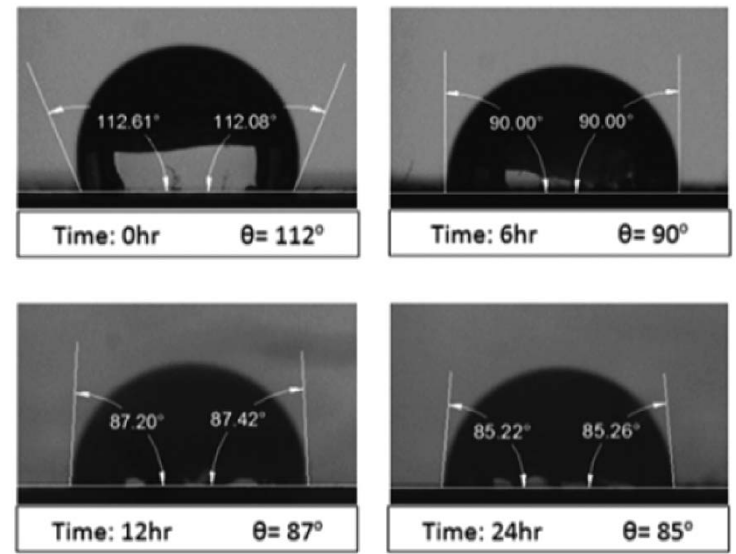

Fig. 7 Contact Angle Changes in Presence of LSW-13 $\left(\mathrm{MgCl}_{2}\right.$ 500 ppm)—Crude Oil A

\section{2. $\mathrm{NaCl}$ Composition}

For this case, still both crude oils create different effects on contact angle changes. As shown in the Fig. 13A), in the first $12 \mathrm{~h}$, the contact angle decreases rapidly. From 12 to $24 \mathrm{~h}$, the contact angle decreases slowly. Here, for the whole span of $24 \mathrm{~h}$, the LSW-01 composition causes greatest change of contact angle $\left(112\right.$ to $\left.73^{\circ}\right)$. In addition, the LSW-06 composition causes minimum change $\left(110\right.$ to $\left.85^{\circ}\right)$. In the Fig. 13B), it is clear that the same compositions and
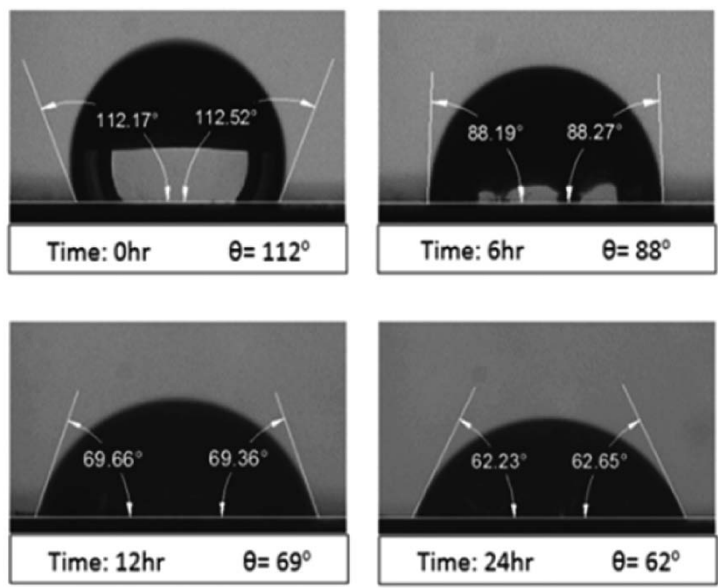

Fig. 8 Contact Angle Changes in Presence of LSW-19 (KCl500 ppm)—Crude Oil A
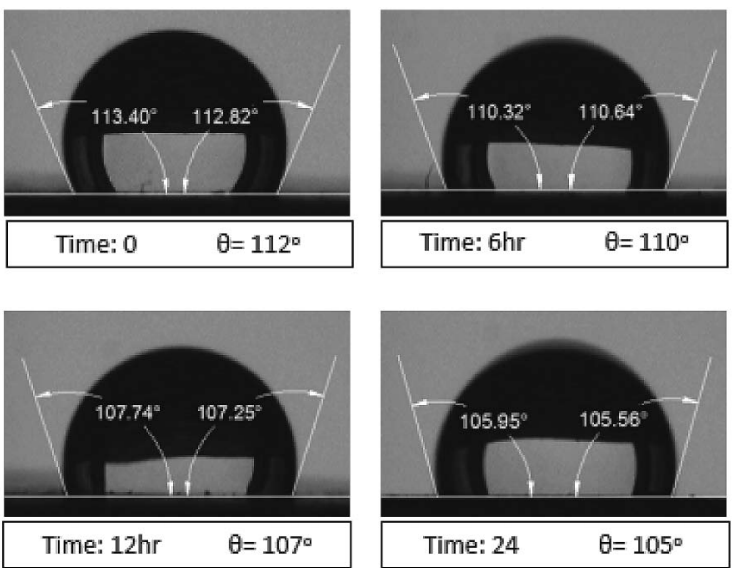

Fig. 9 Contact Angle Changes in Presence of Formation Water (FW-130,000 ppm)—Crude Oil B

concentrations create different effects on contact angle. There is a steady and rapid decrease in contact angle from zero to $6 \mathrm{~h}$. However, from 6 to the end of $24 \mathrm{~h}$, the decrease in contact angle is slow and not steady. Moreover, changes of contact angle are greater than in the Fig. 13A). Moreover, for crude oil B, the LSW01 composition presents greatest changes of contact angle $\left(112\right.$ to $\left.65^{\circ}\right)$, while LSW-06 causes least changes (111 to $\left.80^{\circ}\right)$. 

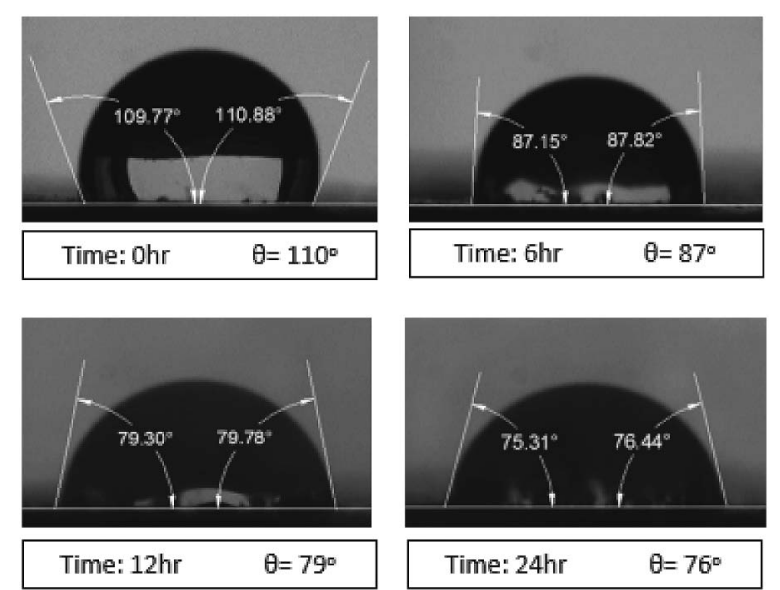

Time: $12 \mathrm{hr} \quad \theta=79^{\circ}$

Fig. 10 Contact Angle Changes in Presence of LSW-13 $\left(\mathrm{MgCl}_{2-}\right.$ 500 ppm)_Crude Oil B
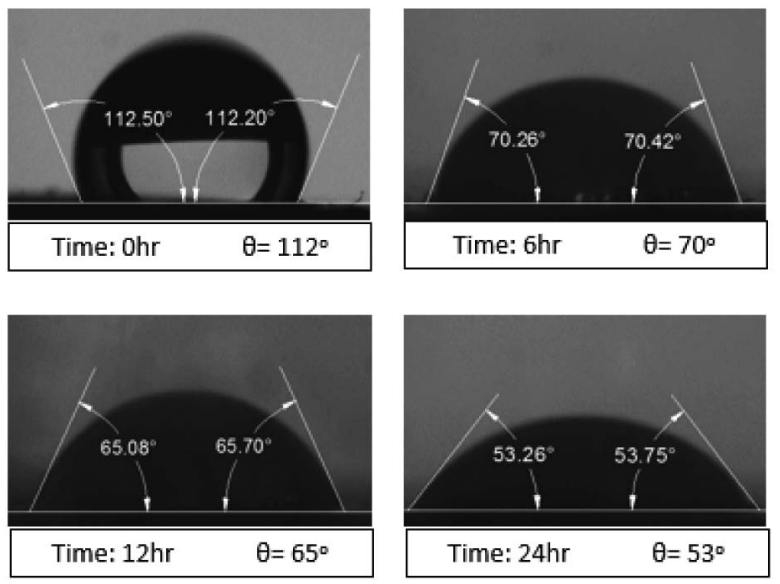

Fig. 11 Contact Angle Changes in Presence of LSW-19 (KCl500 ppm)—Crude Oil B

\section{3. $\mathbf{C a C l}_{2}$ Composition}

The third case consists in verifying the changes of contact angle with time for the $\mathrm{CaCl}_{2}$ brine composition. As displayed in the Fig. 14, the contact angle is decreasing with time. For both Figs. 14A) and 14B), the contact angle decreases rapidly for the first $6 \mathrm{~h}$. However, from 6 to $24 \mathrm{~h}$ the decrease in contact angle is slow. In the interval of $24 \mathrm{~h}$, both crude oil A and B create distinct effects on the contact angle. Figure 14A) shows changes of contact angle for the crude oil A. Here, at the end of $24 \mathrm{~h}$, the composition LSW-07 causes maximum changes of contact angle $\left(112\right.$ to $\left.78^{\circ}\right)$. In contrast, LSW-12 causes minimum change $\left(112\right.$ to $\left.94^{\circ}\right)$. Figure 14B) displays contact angle changes for crude oil B. As shown, at the end of $24 \mathrm{~h}$, still the LSW-07 composition creates maximum changes of contact angle ( 110 to $\left.71^{\circ}\right)$ and LSW-12 creates least changes $\left(111\right.$ to $\left.90^{\circ}\right)$. Furthermore, from the Fig. 14, it is patent that changes of contact angle for crude oil B are greater than of crude oil A for the whole

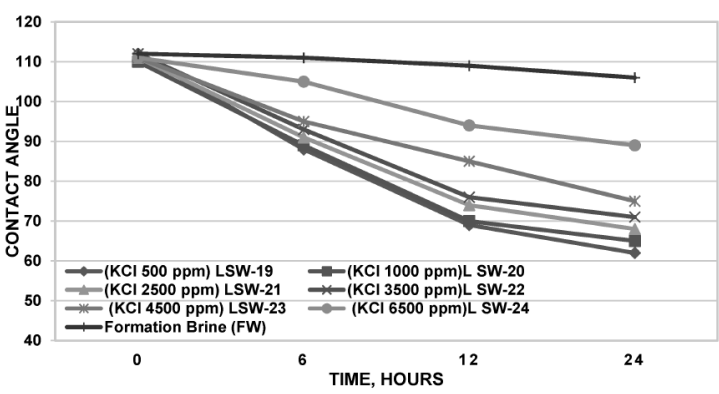

A) Contact Angle versus Time for KCl Composition and Crude Oil A

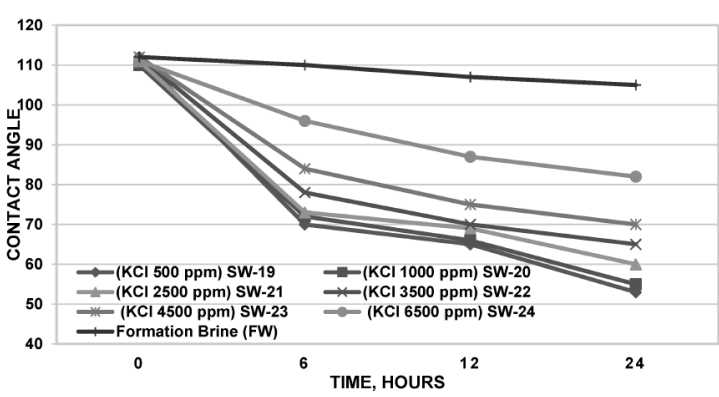

B) Contact Angle versus Time for $\mathrm{KCl}$ Composition and Crude oil B

Fig. 12 Contact Angle Changes for $\mathrm{KCl}$ Composition

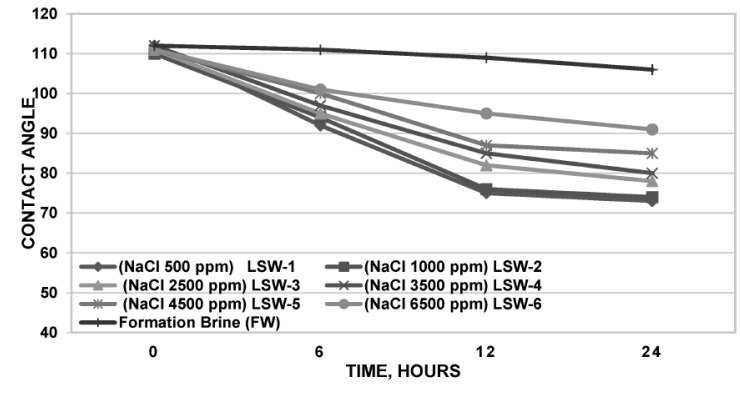

A) Contact Angle versus Time for $\mathrm{NaCl}$ Composition and Crude Oil A

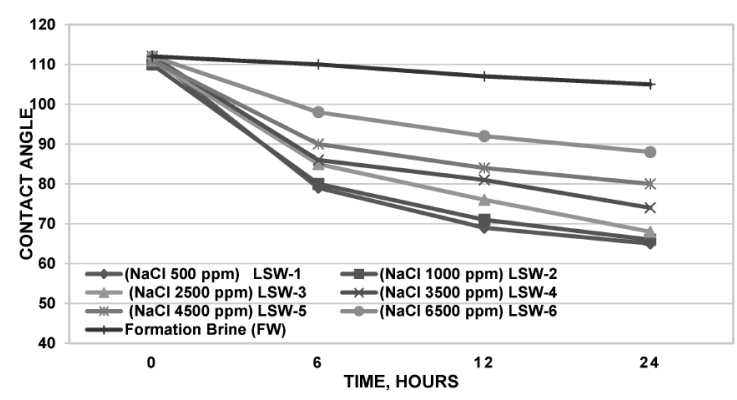

B) Contact Angle versus Time for $\mathrm{NaCl}$ Composition and Crude Oil B

Fig. 13 Contact Angle Changes for $\mathrm{NaCl}$ Composition

span of time.

\section{4. $\mathrm{MgCl}_{2}$ Composition}

The fourth case relates changes of contact angle with time for $\mathrm{MgCl}_{2}$ composition. The contact angle is decreasing with time for the set intervals of time. Both crude oil A and B create different changes of contact 


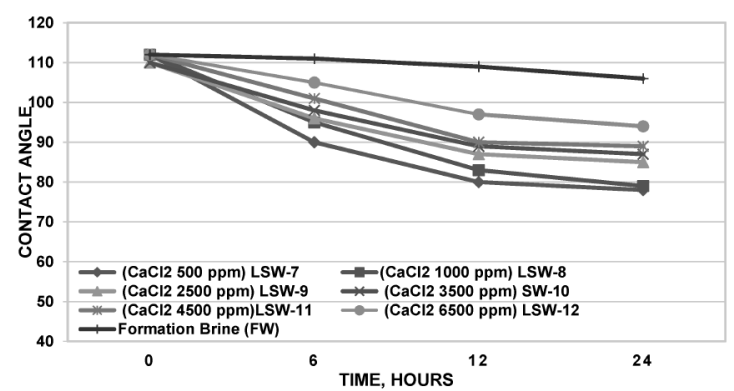

A) Contact Angle versus Time for $\mathrm{CaCl}_{2}$ Composition and Crude Oil A

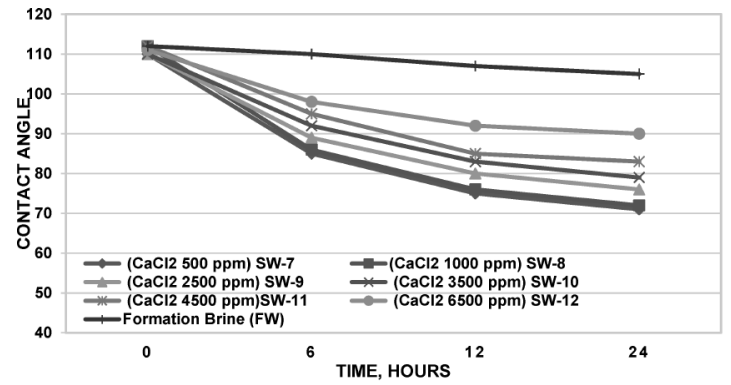

B) Contact Angle versus Time for $\mathrm{CaCl}_{2}$ Composition and Crude Oil B

Fig. 14 Contact Angle Changes for $\mathrm{CaCl}_{2}$ Composition

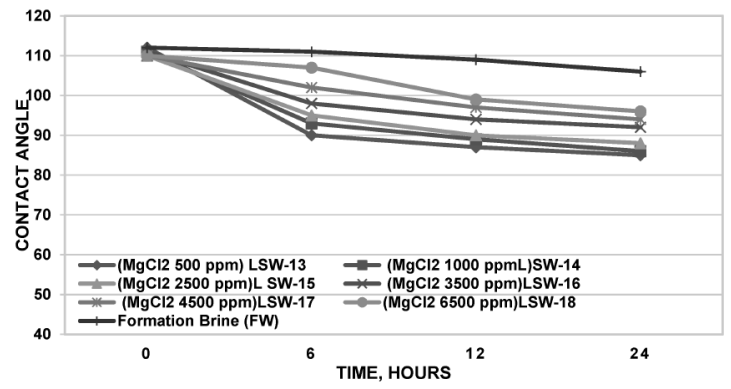

A) Contact Angle versus Time for $\mathrm{MgCl}_{2}$ Composition and Crude Oil $\mathrm{A}$

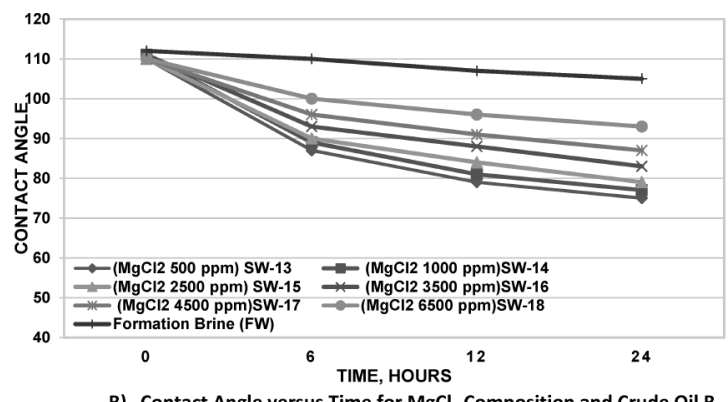

B) Contact Angle versus Time for $\mathrm{MgCl}_{2}$ Composition and Crude Oil B

Fig. 15 Contact Angle Changes for $\mathrm{MgCl}_{2}$ Composition

angle. Moreover, as shown in the Fig. 15, the changes of contact angle for crude oil A are slower and relatively smaller than of crude oil B. Additionally, for both crude oils, within the first $6 \mathrm{~h}$, the changes of contact angle are rapid. From 6 to $24 \mathrm{~h}$, the changes are slow. From Fig. 15A) and interval of $24 \mathrm{~h}$, the composition LSW-13 causes maximum changes of contact angle

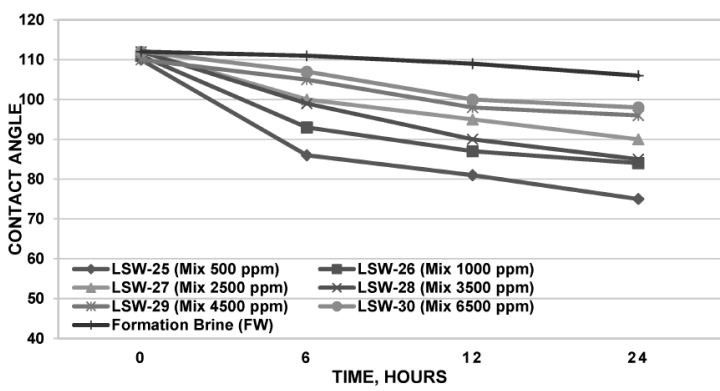

A) Contact Angle versus Time for Mix Composition and Crude Oil A

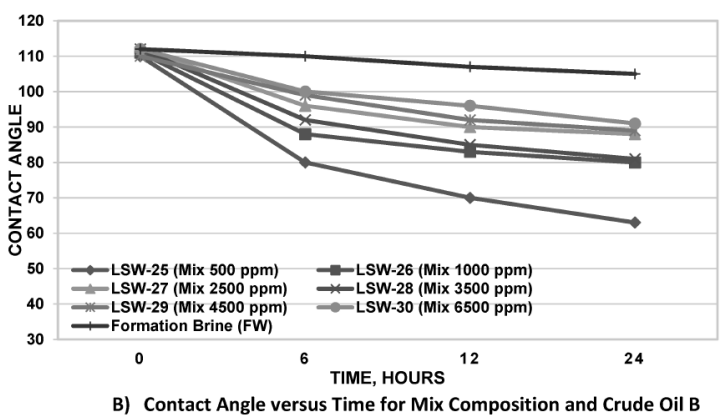

Fig. 16 Contact Angle Changes for Mix Composition

(112 to $85^{\circ}$ ). In contrary, LSW-18 creates minimum changes (110 to $96^{\circ}$ ). For crude oil B (Fig. 15B)), the composition LSW-13 creates maximum changes of contact angle $\left(110\right.$ to $\left.75^{\circ}\right)$. In contrast, LSW-18 creates minimum changes of contact angle, that is, from 110 to $93^{\circ}$.

\section{5. Composition}

The last case is representative of contact angle changes for the mix composition. As shown in the Fig. 16, at each time interval, the contact angle is decreasing. Similar to the previous cases, the effects created by both crude oil A and B are different. Here, contact angle changes for the crude oil A are lesser and slower for each composition than of crude oil B.

From Fig. 16A), there is a rapid decrease of contact angle for the first $6 \mathrm{~h}$. From 6 to the end of $24 \mathrm{~h}$ the decrease is slow with exception to the LSW-25 that presents quite fast decrease. Here, the LSW-25 creates maximum changes of contact angle $\left(110\right.$ to $\left.75^{\circ}\right)$. On the other hand, the LSW-30 composition creates least changes of contact angle $\left(112\right.$ to $\left.98^{\circ}\right)$. For crude oil B (Fig. 16B)), still the contact angle decreases rapidly in the first $6 \mathrm{~h}$. However, from 6 to $24 \mathrm{~h}$, the decrease is slow with the LSW-25 showing slightly faster decrease. The LSW-25 composition causes maximum changes of contact angle (110 to $\left.63^{\circ}\right)$, while LSW-30 causes minimum changes $\left(112\right.$ to $\left.91^{\circ}\right)$. 


\section{Discussion}

We observe that at fixed concentration of LSW, the changes of rock wettability in presence of crude oil $\mathrm{B}$ (with higher TBN and lower TAN) are greater than those in presence of crude oil A (with higher TAN and lower TBN). Skauge et al. (1999) has reported similar results. The author used core samples of sandstone lithology and verified that the wettability changed to more oil wet conditions at higher acid number and to more water-wet conditions at higher base number ${ }^{11)}$. There are several mechanisms behind this behavior. First, the polar components present in the oil phase may be ionized depending on the $\mathrm{pH}$ value. The ionization of basic material results in positively charged crude oil components; while the ionization of acidic material results in negatively charged crude oil components ${ }^{12)}$. These hypotheses are important in understanding the system described below.

We examine an oil/brine/rock system where the formation brine consists mostly of divalent cations, before LSW injection. The presence of these ions results in formation of a water film between the rock and the crude oil ${ }^{13)}$. The water film is positively charged, thus it attracts more the negatively charged crude oil acidic components than does for the positively charged crude oil basic components. Therefore, if we consider the crude oil as characterized with higher TAN and lower TBN, it would have established more oil-wet conditions (say system A); whereas, that with crude oil of higher TBN and lower TAN would have created less oil-wet conditions (say system B). Since the system A is more oil wet, we do not expect significant changes of this wettability state upon LSW injection because the acidic components are tightly held through the water phase. However, for the system $\mathrm{B}$, there will be significant change of wettability because the basic components are loosely held through the water phase. This explains the least changes in wettability for crude oil A as compared to crude oil B.

From the results it is also observed that for both crude oils $\mathrm{A}$ and $\mathrm{B}$, the $\mathrm{KCl}$ composition causes the greatest changes of wettability followed by $\mathrm{NaCl}$, then $\mathrm{MgCl}_{2}$, next $\mathrm{CaCl}_{2}$, and finally the mix composition. Thus if we assume the MIE mechanism, then the easiness of replacement of $\mathrm{Ca}^{2+}$ and $\mathrm{Mg}^{2+}$ cations from the rock surfaces is of order $\mathrm{K}, \mathrm{Na}, \mathrm{Ca}$ and finally $\mathrm{Mg}$. That is, a LSW composed of $\mathrm{KCl}$ at appropriate concentration, will readily replace most of $\mathrm{Mg}^{2+}$ or $\mathrm{Ca}^{2+}$ cations than would $\mathrm{Na}^{+}, \mathrm{Ca}^{2+}$ and $\mathrm{Mg}^{2+}$. This is true and possibly explained based on the reactivity series (RS). From the reactivity point of view, $\mathrm{K}^{+}$is the most reactive and thus it would easily react and bond to the clay surfaces. The second most reactive is $\mathrm{Na}^{+}$, then $\mathrm{Ca}^{2+}$ and finally $\mathrm{Mg}^{2+}$. Therefore, from the results, their reactivity series for a LSW flooding can be reformulated as follows: $\mathrm{K}^{+}>\mathrm{Na}^{+}>\mathrm{Ca}^{2+}>\mathrm{Mg}^{2+}$. Regarding the aforementioned, it becomes necessary to add one more condition for the MIE mechanism. This condition supports that the replacement of the divalent cations follows the reactivity series termed as MIE-RS.

\section{Conclusions}

The changes in wettability of a certain reservoir are affected by the polar components present in the crude oil. Their characterization is performed through measurements of the crude total acid number (TAN) and total base number (TBN). The magnitude of the change of wettability is dependent on the concentration of the components. Here, there is much change of wettability when there is high TBN and low TAN.

The changes of rock wettability are not only dependent on the concentration of crude oil polar components, but also on the composition and concentration of the brine. From the experiment, greatest changes of wettability for both crude oil A and crude oil B were experienced for $\mathrm{KCl}$ composition at $500 \mathrm{ppm}$ followed by the $\mathrm{NaCl}$ at $500 \mathrm{ppm}$.

Furthermore, a new mechanism, MIE-RS, is proposed which could open the gates for future studies on wettability alteration upon LSW flooding. However, it has no laboratory basis; therefore, it is only well suited for future work.

\section{Nomenclatures}

\begin{tabular}{|c|c|c|}
\hline LSW & : low salinity water & \\
\hline TAN & : total acid number & \\
\hline TBN & : total base number & \\
\hline TDS & : total dissolved solids & \\
\hline MIE & : multiple-component ion exchange & \\
\hline $\mathrm{KOH}$ & : potassium hydroxide & \\
\hline IFT & : interfacial tension & \\
\hline RS & : reactivity series & \\
\hline$b$ & : slip factor & [psi] \\
\hline$K$ & : liquid permeability & {$[\mathrm{mD}]$} \\
\hline$K_{\mathrm{g}}$ & : gas permeability & {$[\mathrm{mD}]$} \\
\hline$V_{\mathrm{b}}$ & : sample bulk volume & {$\left[\mathrm{cm}^{3}\right]$} \\
\hline$V_{\mathrm{g}}$ & : grain volume & {$\left[\mathrm{cm}^{3}\right]$} \\
\hline$V_{\mathrm{p}}$ & : pore volume & {$\left[\mathrm{cm}^{3}\right]$} \\
\hline \multicolumn{3}{|c|}{$<$ Greeks $>$} \\
\hline$\beta$ & : inertial resistivity & {$\left[\mathrm{ft}^{-1}\right]$} \\
\hline$\varphi$ & : sample porosity & {$[\%]$} \\
\hline
\end{tabular}

\section{References}

1) Nasralla, R. A., Alotaibi, M. B., Nasr-El-Din, H. A., Western North American Region Meeting, Anchorage, Alaska, USA, 2011, SPE 144602-MS

2) Tang, G. Q., Morrow, N. R., J. Petrol. Sci. Eng., 24, 99 (1999).

3) McGuire, P. L., Chatham, J. R., Paskvan, F. K., Sommer, D. M., Carini, F. H., Western Regional Meeting, Irvine, California, USA, 2005, SPE 93903.

4) Morrow, N. R., Tang, G. Q., Valat, M., Xie, X., J. Petrol. Sci. 
Eng., 20, (3-4), 267 (1998).

5) Lager, A., Webb, K. J., Black, C. J. J., Singleton, M., Sorbie, K. S., International Symposium of the Society of Core Analysis, Trondheim, Norway, 2006, SCA 2006-36.

6) Ligthelm, D. J., Gronsveld, J., Hofman, J. P., Brussee, N. J., Marcelis, F., van der Linde, H. A., EUROPEC/EAGE Annual Conference and Exhibition, 2009, SPE 119835.

7) Fanchi, J. R., "Integrated Reservoir Asset Management: Principles and Best Practices," Elsevier Gulf Professional Publishing, Burlington, MA 01803, USA, 2010.

8) Guggenheim, S., "MSA Monograph: Teaching Mineralogy," eds. by Brady, J. B., Mogk, D. W., Perkins, D. III, Mineralogical Society of America, (1997), pp. 371-388.
9) Green, D. W., Willhite, G. P., "Enhanced Oil Recovery (SPE textbook series)," Society of Petroleum Engineers, Vishal Raj, Texas, USA (1999).

10) Shabib-Asl, A., Ayoub, M. A., Kermanioryani, M., Valentim, P. P. J., J. Natural Sciences and Research, 4, 13 (2014).

11) Skauge, A., Standal, S., Boe, S. O., Skauge, T., Blokhus, A. M., Annual Technical Conference and Exhibition, Houston, Texas, USA, 1999, SPE 56673.

12) Cuiec, L., Annual Technical Conference and Exhibition, Dallas, USA, 1975, SPE 5634.

13) Kaliyugarasan, Master thesis, Centre for Integrated Petroleum Research (CIPR), Department of Chemistry, University of Bergen, Norway, (2013). 